Winter 2009

\title{
Civil Society and Disability Rights in Post-Soviet Ukraine: NGOs and Prospects for Change
}

Sarah D. Phillips

Indiana University

Follow this and additional works at: https://www.repository.law.indiana.edu/ijgls

Part of the Civil Law Commons, International Law Commons, and the Law and Politics Commons

\section{Recommended Citation}

Phillips, Sarah D. (2009) "Civil Society and Disability Rights in Post-Soviet Ukraine: NGOs and Prospects for Change," Indiana Journal of Global Legal Studies: Vol. 16 : Iss. 1 , Article 10.

Available at: https://www.repository.law.indiana.edu/ijgls/vol16/iss1/10

This Symposium is brought to you for free and open access by the Law School Journals at Digital Repository @ Maurer Law. It has been accepted for inclusion in Indiana Journal of Global Legal Studies by an authorized editor of Digital Repository @ Maurer Law. For more information, please contact rvaughan@indiana.edu.

\section{$\Psi$}

JEROME HALL LAW LIBRARY

INDIANA UNIVERSITY

Maurer School of Law
Blooming ton 


\title{
Civil Society and Disability Rights in Post-Soviet Ukraine: NGOs and Prospects for Change
}

\author{
Sarah D. Phillips*
}

\begin{abstract}
This article uses an anthropological approach to critically examine the limitations and successes of the contemporary disability rights movement in post-Soviet Ukraine. Case studies of rights legislation and the work of disability advocacy NGOs are detailed to illustrate the paradoxes and problems that imbricate disability rights issues, and the strategies some activists have leveraged to successfully navigate these challenges. The article suggests specific tactics that rights groups in Ukraine might pursue to further enact change in their communities, including pursuing more international partnerships, fielding candidates for political office, and launching informational and image campaigns.
\end{abstract}

\section{INTRODUCTION}

In 1998, representatives of a non-governmental organization (NGO) for the disabled in the small city of Lutsk, Ukraine, organized an event called "Divis na mene, iak na riunoho" ("Look at me as an equal") to draw attention to the problems of people who use wheelchairs - a population that was marginalized and made nearly invisible in the Soviet Union. Divis na mene focused on the benefits of "active rehabilitation," an empowerment strategy introduced in Ukraine in the mid-1990s by Swedish rights activists that enables wheelchair users to independently navigate architectural barriers such as curbs and stairs. The demonstration took place on a central street in Lutsk, and participants were invited from all over

* Assistant Professor of Anthropology, Indiana University-Bloomington. I am grateful to the many people in Ukraine who have assisted my research endeavors, especially Oleg Poloziuk, Olga Alekseeva, Nina Syedina, Yaroslav Hrybalskyy, Mykola Swarnyk, and Oksana Kunanec-Swarnyk.

Indiana Journal of Global Legal Studies Vol. 16 \#1 (Winter 2009)

CIndiana University Maurer School of Law - Bloomington 
Ukraine. This first Divis na mene was deemed a success, and NGOs in other Ukrainian cities began to host it annually on a rotating basis.

In 2003, Divis na mene was held in Kyiv, the capital city, now under the auspices of government ministries dealing with disability issues. The event took place on Kyiv's major thoroughfare, Khreshchatyk, where passersby stopped to observe people in wheelchairs playing basketball, dancing, going up and down stairs, and driving cars. Two narrators carried out a scripted conversation by microphone designed to educate the public about active rehabilitation and the many possibilities for the disabled to enjoy an active, fulfilling life.

The 2005 Divis na mene demonstration, while similar in form, was held in a very different venue. In a move attributed to concerns about the weather-even though it turned out to be a beautiful day--the demonstration took place not on Khreshchatyk, but behind closed doors in a large hall in Kyiv's City Administration Building. Because special passes were necessary to enter the building, the only spectators included participants' friends and family members and a few representatives of state ministries. As one participant put it, "We put on the show for ourselves." His wife explained, "It is convenient for them to do this, to say that 'the laws are in effect,' and then hide people behind closed doors. This is big politics."

How did a small, grassroots, disability rights demonstration, after migrating to Kyiv and ascending the steps of the City Administration Building, end up behind closed, guarded doors? I believe this situation is symptomatic of the uneven successes of the Ukrainian disability rights movement during the past two decades. On the one hand, some grassroots NGOs, like the one in Lutsk, have pursued creative and effective strategies to improve public attitudes toward persons with disabilities, have influenced state officials and local elites, and have had a positive impact in the disability community. On the other hand, the story of the Divis na mene demonstrations evinces processes of elite capture of disability rights issues in the years since Ukrainian independence. This article will examine some of these processes, highlight a few of the major successes and shortcomings of the disability rights movement in Ukraine, and offer suggestions for strengthening civil society initiatives for disability advocacy in that country.

This article is founded upon eight months of ethnographic fieldwork that I conducted with representatives of the Ukrainian disability rights movement since 2002. ${ }^{1}$ This research is part of a larger study of the politics of disability, welfare reform, and changing citizenship regimes in Soviet and post-Soviet Ukraine. My research has focused primarily on persons with mobility disabilities, especially

1. Records and transcripts of the research are on file with the author. 
wheelchair users, as a population that has been targeted by international, state, and NGO advocacy efforts since Mikhail Gorbachev's policies of glasnost (openness) and perestroika (restructuring). In 1991, the success of Ukrainian independence availed more opportunities for collective action and transnational contacts in the disability rights sphere. ${ }^{2}$ Within the disability rights movement, persons with mobility disabilities have been especially visible. This is in part thanks to Valery Sushkevych, a Member of Parliament and major political figure who uses a wheelchair after having survived childhood polio. In his capacity as head of the Ukrainian Paralympic Committee, chairperson of the National Sports Committee for Disabled Citizens of Ukraine, and head of an NGO coalition called the National Assembly of the Disabled of Ukraine (NADU), Sushkevych has promoted disability awareness by focusing largely on disability sports.

In 2002, I began participant observation and semi-structured interviews with representatives of a range of disability-related NGOs whose work I have followed for five years. ${ }^{3}$ For this study, I have examined the activities of twenty-six disability rights NGOs from all over Ukraine. For the purposes of this paper, I rely primarily on participant observation with NGOs, interviews, and informal conversations with Ukrainian NGO activists.

\section{Context: Locating Rights Activism on the Ground}

In Ukraine, the disability rights movement-which includes hundreds of NGOs as well as official state structures-is one of the most dynamic yet understudied post-Soviet social movements. Since the early 1990s, a range of non-governmental and quasi-governmental organizations have emerged to raise public awareness about disability rights, provide services, conduct lobbying efforts, and

2. Most persons involved in this study have experienced traumatic spinal cord injuries (primary causes included diving accidents, falls from heights, automobile accidents, and gunshot wounds). Other participants include persons with cerebral palsy, muscular dystrophy, multiple sclerosis, spinal tumors, or underdeveloped limbs, as well as amputees and those with post-polio disablement. Over the last decade, such persons have come to be identified (and to self-identify) with the general category of "wheelchair users" (vizochnyki) or spinal'niki (a colloquial term denoting persons with spinal cord and spinal injuries or diseases). People with tuberculosis of the spine, spinal meningitis, hernias, spinal hemorrhaging, and rheumatoid arthritis are often also included. See LEV INDOLEv, ZHIT' v KOLIASKE [TO LIVE IN A WHEELCHAIR] 11-25 (2001).

3. In total I have conducted nearly ninety personal interviews with activists, policymakers, scholars, educators, lawyers, medical professionals, and others, including life history interviews with fifteen disability rights activists from different regions of Ukraine representing diverse age, ethnic, gender, and socioeconomic backgrounds. 
take advantage of funding opportunities provided by international development organizations. Today, of the nearly eighteen thousand civic and charitable organizations in Ukraine, around nine hundred focus their activities on disability issues, and there are at least thirty-eight registered NGO coalitions addressing issues of disability. ${ }^{4}$ Charities, support groups, and organizations focusing on sports, the arts, entrepreneurship, and other endeavors offer opportunities for people with disabilities to receive support and become part of new social networks. In many cases, these interactions have offered persons with disabilities opportunities for self-realization and new ways of perceiving themselves as citizens. However, there are disconnects between the small-scale successes that groups working in specific communities have achieved and the "big politics" of disability rights at the national level.

Official statistics in Ukraine indicate that roughly 2.6 million persons (5.3 percent of the population) in Ukraine are considered disabled, ${ }^{5}$ but this statistic includes all types and levels of disability, including disability associated with the 1986 Chernobyl nuclear disaster. As Oleg Poloziuk has stated, due to a lack of detailed statistical information, the mobility disabled in Ukraine constitute an "unknown" segment of the population. ${ }^{6}$ Recent studies in Ukraine report that there are around thirtytwo thousand people with spinal injuries and note that most injured persons are between twenty and forty-five years old. According to the available statistical analyses provided by neurosurgical departments of medical institutions from 1994 to 2001 , between those years an average of 2,066 persons suffered spinal cord injuries in Ukraine each year, the number increasing by ninety-one injuries each year. ${ }^{7}$ There are no statistics available to quantify the number of disabled children and adults who are wheelchair users as a result of disease, but we know the number is significant, since this population is provided with between twenty thousand and

4. See Pro stanovyshche invalidiv $V$ YKRaINi ta osnovy derzhavnol polityky SHChodo VYRISHENNIA PROBLEM HROMADIAN Z OSOBLYVYMY POTREBAMY [THE CONDITION OF THE Disabled in Ukraine and the Bases of State Politics to Address the Problems of Citizens with SpeCial Needs] 122 (2002) (Ukr.) [hereinafter Pro stanovyshChe] (delineating a multi-site project that includes the perspectives of persons with disabilities from different areas of Ukraine, an important consideration in a country characterized by significant regional differences in local economies, available medical and rehabilitation services, the existence or absence of disability rights NGOs, and the attitudes of representatives of local governments).

5. Id. at 5 .

6. Oleg Poloziuk, Problems of Socio-Legal Protection of Disabled Persons with Spinal Cord Injuries in Ukraine, Presentation at the Sixth Congress of the International Association of Ukrainian Studies, Donetsk, Ukraine 5 (June 29-July 1, 2005) (on file with author).

7. Id. at 1 . 
thirty thousand wheelchairs annually. ${ }^{8}$ Some activists estimate that around five thousand wheelchair users live in Kyiv, the capital city.

Major foci of the disability rights movement in Ukraine today include the improvement of medical services, the formulation of a comprehensive system of post-trauma rehabilitation, the provision of suitable wheelchairs and other equipment, the deinstitutionalization of children with disabilities, the guarantee of equal access to quality education, equal opportunity for jobs for the disabled, and the introduction of accessible transport and public spaces and buildings. Most of these foci mirror the concerns of Disabled People's International (DPI), which has recognized and codified the following basic human rights of the disabled as essential for full societal participation: education, employment, economic security, services, independence, culture and recreation, influence or political participation, the right to life, and the right to parenthood. ${ }^{10}$

In some ways, quality of life for people with mobility impairments has improved considerably since perestroika and the collapse of the Soviet Union. The level of accessibility is improving, albeit slowly, and there are some examples of handicapped accessible public transportation, buildings, sidewalks, and public spaces in major cities. The disabled are being offered more opportunities to pursue higher education. ${ }^{11}$ Indeed, almost all the young people with disabilities I met in Ukraine are enrolled in some form of higher education. Although many disabled persons continue to study through correspondence courses due to lack of accessibility and difficulties with housing and finances, there is widespread recognition that education is increasingly vital in today's world. These young people express some hope that they will find jobs with their degrees. Additionally, comprehensive legislation is in place guaranteeing the disabled equal rights in employment. These improvements in infrastructure and life possibilities, however, are accompanied by a range of injustices that compel many people with disabilities in Ukraine to feel as if they live in a parallel world where their rights to full citizenship in the new Ukrainian state are circumscribed.

8. This lack of statistics also characterizes the Russian case. Through compiling the scant available data and carrying out elaborate guesswork, journalist and activist Lev Indolev estimates around there are ten thousand persons with spinal injuries living in Russia and a total of 250,000-300,000 children and adults who use wheelchairs. See INDOLEv, supra note 2, at 7-9.

9. Interview with Nina Syedina, Dir., ARIS, in Kyiv, Ukr. (June 12, 2005).

10. Colin Barnes et al., Exploring Disability: A Soctological Introduction 97 (1999).

11. Sharon A. Raver, The Emergence of Inclusion for Students with Disabilities in Ukraine, 22 INT'L J. SPECial Educ. 32, 35 (2007). 


\section{Slippages and Stoppages in Disability Rights}

On the surface, the concerns articulated by disability rights activists appear to have been addressed in meaningful ways in new state programs and legislation. However, profound disconnects exist between disability legislation adopted at the state level (legislation that, in general, conforms to international norms to guarantee the disabled equal rights in health care, education, employment, housing, accessibility, and other areas) and the everyday reality experienced by persons with disabilities. A few examples of these disconnects include the following:

- In 1992, the Ministry of Health approved the "Provision on the individual program of rehabilitation and adaptation of the invalid (IPRI),"12 and the "Method of formulating the individual plan of rehabilitation and adaptation of the invalid."13 The IPRI plan represents a significant step toward a state system of rehabilitation that would focus not only on medical and technical problems of the disabled but would also integrate economic and social concerns. Unfortunately, a mechanism for funding the IPRI process was not approved until 2003 (the program is to be funded through local branches of the Ukrainian Fund for the Social Protection of Invalids (FSPI)), and the program has yet to be implemented. Furthermore, most people who have been granted disability by the Ministry of Health are unaware of the IPRI program.

- On June 1, 2005, President Viktor Yushchenko signed Decree No. 900, “On Immediate Measures for Creating Favorable Conditions of Living for Persons with Limited Physical Capabilities," that outlines steps to be taken to provide for equal access to "objects of social infrastructure"14 to people with disabilities. The Decree highlights the need for accommodations such as handicapped-accessible public transportation (including train cars and school buses), parking spaces, government buildings, dormitories, and underground walkways. It challenges the State Committee of Ukraine on Building and Architecture and the State Committee on Housing to begin taking steps toward adopting European Union standards for guaranteeing persons with disabilities equal access to public spaces. However, existing laws on disability

12. Poloziuk, supra note 6 , at 2.

13. Id.

14. Ukaz Prezydenta Ukrainy [Decree of the President of Ukraine], $900 / 2005$ (Ukr.), available at http://naiu.org.ua/index.php? option $=$ com_content $\&$ task $=$ view $\&$ id $=99 \&$ Itemid $=87$ (last visited Oct. 28, 2008) [hereinafter Decree No. 900]. 
are only financed at $12-18$ percent, ${ }^{15}$ and this and other recent legislation is poorly enforced, if at all.

- As of 2002, only 14.5 percent of persons considered disabled were employed, and disabled workers made up only 1.6 percent of the Ukrainian workforce. ${ }^{16}$ Attempts to usher disabled workers into the workforce were made through the introduction of a 2001 change to the Law on the Basis of Social Protection of Invalids (No. 2606-III). ${ }^{17}$ This law requires that each employer hire a certain percentage of workers with disabilities. According to Article 20 of this law, employers who are unwilling to comply must pay a fine to the All-Ukrainian Fund of Social Protection of the Disabled. However, Article 20 contains many loopholes and many, if not most firms, skirt these regulations either by simply paying the relatively small fine or by pretending to hire disabled workers.

Although Ukrainian legislation governing disability rights reflects worldwide standards of inclusion and protection, and despite a proliferation of state and NGO advocacy programs, the rights of the disabled are consistently and blatantly violated. Overall, these slippages signal a change in the laws without a concomitant change in attitudes, a lack of public interest in disability rights, and an absence of real political will vis-à-vis disability issues at high levels of government. It is this intersection of what some of my sources call the "beautiful" or "fairy tale" laws guaranteeing disability rights and the everyday reality of living with a disability that has prompted many rights activists to found disability advocacy NGOs. There are some success stories to be told, stories that provide examples of how, despite many obstacles, rights activists have made changes in their communities. Before turning to these stories, however, it is important to outline the difficulties that would-be NGO organizers face in post-Soviet Ukraine. Although some of these challenges are particular to post-socialist states, others will be familiar to NGO activists in other world regions.

15. Interview with Valery Sushkevych, President, Nat'l Comm. of Sports for the Handicapped, in Kyiv, Ukr. (May 29, 2005).

16. Pro stanovyshche, supra note 4 , at $96-97$.

17. Vidomosti Verkhovnoi Rady (VVR), [News of the Parliament] 45 (Ukr.), available at http:// naiu.org.ua/index.php?option $=$ com_content $\&$ task $=$ view $\&$ id $=57 \&$ Itemid $=75$ (last visited Oct. 28 , 2008). 


\section{Corruption, Competition, and Coalition: Challenges for NGOS}

There are four major types of challenges that confront those seeking to carry out social activism through organizations such as NGOs. The challenges can be grouped as institutional, perceptual-social, interactional, and hierarchical.

\section{A. Institutional Challenges}

Despite the assessment by some NGO experts that there are "no serious legal limitations as to the registration of civic and charitable organizations" in Ukraine, ${ }^{18}$ most of my sources reported that officially registering organizations can be an onerous task. Registration procedures are confusing and often contradictory, and many NGO activists have found it difficult to obtain information on legislation governing civic organizations. NGO resource centers have been established in major cities, especially Kyiv, but many activists have been unable to access them.

Overall, the legal environment in Ukraine is not conducive to the development of a vibrant NGO sphere. NGOs enjoy few tax benefits. For example, there is little incentive for businesses or individuals to make charitable donations. Those tax benefits that NGOs do enjoy put activists at risk of being enticed into illegal activity. Since NGOs can receive shipments of humanitarian aid duty-free, for example, many of my sources were approached by business representatives who asked them to import consumer goods for them under the guise of humanitarian aid. Although NGOs in Ukraine have not been subject to the same kind of scrutiny and pressure that NGOs in Russia have faced in recent years, ${ }^{19}$ some Ukrainian NGO activists have been harassed by representatives of the state.

\section{B. Perceptual-Social Challenges}

In part due to these institutional constraints, which foster corruption, societal perceptions of NGOs tend to be quite negative. Those outside the NGO sphere may be suspicious of the motives of NGO activists; one disability rights activist said that most of his disabled acquaintances distance themselves from NGOs, be-

18. Oleksander Sydorenko, Civic and Charitable Organizations in Ukraine, UKRAINIAN NGO MONITOR, May 2000, at 3.

19. Robert C. Blitt, Babushka Said Two Things: It Will Either Rain or Snow; It Either Will or Will Not: An Analysis of the Provisions and Human Rights Implications of Russia's New Law on Nongovernmental Organizations as Told Through Eleven Russian Proverbs, 40 GEo. Wash. INT'L L. Rev. (forthcoming 2008), available at http://papers.ssrn.com/sol3/papers.cfm ?abstract_id = 1016367. 
lieving that NGOs are more about leaders trying to "get something" for themselves than actually seeking social change. These perceptions have prevented some young people from taking part in NGOs. NGO activists tend to be middle-aged representatives of the last Soviet generation, whereas those who came of age after Ukrainian independence are less likely to engage in social activism through civic organization. The long-term effects of this generational gap remain unclear.

\section{Interactional Challenges}

In the context of the post-socialist "transition" to a market-based economy and the concomitant economic and social crises Ukrainians have faced since the late 1980 s, limited resources are available in the non-governmental sector. Therefore, the NGO sphere is highly competitive and NGO actors are often distrustful of one another. Groups with similar agendas and interests compete for resources; information about sponsors, legislation, and project opportunities is at a premium. Furthermore, local government officials and businesspeople are often wary of NGOs, which they perceive as encroaching on their territory and their interests. NGO activists complain that they are compelled to contribute a great deal of time and energy to negotiate conflicts with other civic groups and with local bureaucrats. Such a culture of distrust and secrecy is not conducive to coalition building.

\section{Hierarchical Challenges}

Even when coalitions of NGOs with similar agendas and interests are formed, problems still abound. First, rarely is coalition building in Ukraine an organic process; rather, NGOs are compelled to form coalitions at the behest of representatives of state institutions, who, as a matter of expediency, prefer to work with coalitions rather than with individual organizations. This situation can foment conflict within coalitions, which easily become fragmented.

Coalition building is also plagued by socialist legacies. Some of the largest and most visible coalitions of disability-related NGOs, such as the Union of Organizations of Invalids of Ukraine (SOIU) and the Ukrainian Associations of the Blind and the Deaf (UTOS and UTOG), are heirs of Soviet-era organizations. These groups have unwieldy, rather ossified structures and tend to have a narrow focus on shoring up social programs for certain groups of the disabled. They are characterized by institutional memories ill-equipped to address present-day issues of importance.

Coalitions of disability rights NGOs are also subject to the same kind of elite 
capture that affected the Divis na mene campaigns described earlier. The NADU, a coalition of fifty-eight NGOs founded by Sushkevych in 2001, provides an example. One of the main stated goals of NADU is to advance the constitutional rights and legal interests of disabled persons and their NGOs in the Ukrainian Parliament, Cabinet of Ministers, and other organs of legislative power. ${ }^{20}$ NADU, which is closely tied to the state administration through Sushkevych, is considered a "civic-political" partnership.

On the one hand, this situation has facilitated the passage of important legislation-Sushkevych coauthored the disability rights legislation adopted in 1992 just after Ukrainian independence, and NADU has drafted and lobbied for the passage of important items such as Presidential Decree No. 900 on accessibility. ${ }^{21}$ In contrast, disability-focused civic organizations other than NADU have not pursued lobbying efforts to any meaningful extent, which could be considered problematic. Also, many complain that NADU has too much power and is dismissive of alternative or competing points of view. There is considerable dissatisfaction in some circles with Sushkevych, who some feel has too much sway in disability affairs and has consolidated too much power. As a result, in 2004, the Confederation of Civic Organizations of Invalids of Ukraine (KHOIU) was formed as an alternative to NADU. Some activists predicted that this would produce healthy competition, but thus far, KHOIU has not solidified any significant programs.

Given these formidable institutional, perceptual, interactional, and hierarchical challenges, how can persons and collectives interested in advocating for disability rights issues best proceed? The strategies that some NGO activists have employed to empower disabled members of their communities provide some insight.

\section{IV. “We Began a Dialogue”: Real Change at the Local Level}

\section{A. Case One: Job Placement, Partnership, and Personification}

As described above, despite legislation to facilitate the equal employment of disabled workers, a very low percentage of persons with disabilities in Ukraine are employed (14.5 percent). ${ }^{22}$ The quota system, which requires enterprises to hire a certain number of disabled workers depending on the firm's size, has not

20. Pro stanovyshche, supra note 4 , at 125.

21. Decree No. 900, supra note 14.

22. Pro stanovyshche, supra note 4 , at $96-97$. 
solved the problems of unemployment and under-employment of the disabled. ${ }^{23}$ Iryna, the head of an NGO for the disabled in a small city in central Ukraine, was concerned about employment issues in her town and set up a partnership with the local unemployment office. Iryna became aware that employers regularly contacted the office to seek out disabled workers but that the vacancies offered were exclusively for janitors or for people to do heavy lifting. Iryna realized that more needed to be done to link up employers with disabled job-seekers directly and to dispel negative stereotypes about disabled workers and their supposed "limited potential" among employers. She described the solution she pursued-a job fair:

We had a job fair - we invited directors of firms and enterprises, and people with disabilities....We let them know that among the disabled there are many qualified people. People become disabled at different times in their lives - not necessarily in childhood. People have some educational background. They were really surprised that we have people who can do computer work. And several people were hired right on the spot at the job fair because we began a dialogue. We tried to understand one another and it worked.

Iryna worked through her NGO to address a lack of dialogue between organs of the state (the unemployment office), those of the market (the employers), and citizens with disabilities. She also formulated a strategy to educate local employers about the potential of her NGO members as workers, and to dispel negative stereotypes of the disabled as people who could only perform manual work such as heavy lifting (problematic for many people with disabilities in any case) and janitorial work.

To carry out her approach, Iryna pursued a strategy of personification to advance disability awareness, a tactic used by many of my sources. In a context where the vast majority of citizens had only limited or no contact with the disabled in the Soviet Union, unfamiliarity with "real, live" people with disabilities allowed fear and negative attitudes to proliferate. NGO activists frequently take it upon themselves to, as one woman put it, "personify for others a real, live disabled person." "Starting a dialogue" by personifying disability and fostering new social

23. For a workforce of greater than twenty-five employees, at least $4 \%$ of workers must have a disability. (In an organization with one hundred workers, for example, at least four must have disability status.) Small firms that hire only fifteen to twenty-five workers are required to reserve one job for a disabled worker. See Pro STANOVYSHCHE, supra note 4, at 99. 
networks has proven effective for advancing disability rights at local levels. Other informants described to me how they had used personification strategies to persuade store personnel, for example, to install wheelchair ramps and handicapped accessible toilets. Often this entailed asking the person to "imagine yourself in my position," or actually inviting the person to occupy one's wheelchair. The success of the first Divis na mene demonstration in Lutsk could also be attributed to personification: the event facilitated personal interactions between people with disabilities and others in their community.

\section{B. Case Two: Active Wheelchairs and International Ties}

In the mid-1990s, a woman named Zoia founded an NGO called Lotus, an organization for people with spinal injuries, after her teenage son, Sasha, was injured in a diving accident. Zoia and Sasha, who live in Kyiv, made contact with an advocacy group in Sweden that provided Sasha with an "active" wheelchair-a lightweight and highly maneuverable chair much preferable to the large, heavy wheelchairs available in Ukraine at the time. Around the same time, the Swedes introduced their program of "active rehabilitation" (AR) to Ukrainian wheelchair users. In this program (which continues in Ukraine, now under the auspices of NADU), strategies for AR are introduced to small groups of wheelchair users during an intense, highly structured seven- to ten-day closed camp. At these camps, wheelchair users are exposed to a strict philosophy of individual independence and they receive training in wheelchair sports, overcoming architectural barriers, and independently carrying out activities of daily living.

$\mathrm{AR}$, as developed by the Swedes, cannot take place without lightweight, active wheelchairs. In the early days of the AR camps, the Swedish representatives traveling to Ukraine brought used active wheelchairs for participants to use and keep. This created local demand, and Zoia and Sasha, through their organization Lotus, took up the banner of Ukrainian production of active wheelchairs. For this, the activists needed to convince producers that the venture would be profitable. Zoia and Sasha were also committed to helping improve the quality of life for Ukrainian wheelchair users by ensuring the availability of active wheelchairs for all who could use them. To reach both these goals, they convinced representatives of the Ministry of Labor and Social Policy, one of the bodies responsible for disability benefits, to agree that those who needed them could receive an active wheelchair free from the state as part of their disability benefits. With this agreement, the activists persuaded representatives of a local factory to start domestic 
production of active wheelchairs. Ukrainian wheelchair users are entitled to a new active wheelchair every two years, ${ }^{24}$ and even though this is not always enforced, it represents a milestone in disability rights. Active wheelchairs are now produced by factories in two major cities, Kyiv and Zaporizhzhia.

These positive developments are a result of many factors. Zoia and Sasha acted as mediators to successfully create a partnership between state and business entities. They used their expertise and experience with the many nuances of wheelchair design and use (expertise generally absent among cadres in the Ministry of Labor and Social Policy) to formulate a convincing argument and a concrete plan to reform wheelchair production. Zoia believed that this proactive approach, which she called "social initiative," ingratiated her to state officials. She said, "When the disabled began to show initiative, and began to do something for themselves, then the government started to help." No less important, the activists leveraged their ties with foreign activists (in this case, the Swedes) as a form of cultural and social capital to convince local elites and businesspeople of the feasibility and desirability of their plans. This strategy_playing the international against the national and local--was common and often successful, among activists who had travelled abroad or had international contacts.

\section{Case Three: Accessibility and Local Representation}

As noted above, the creation of a built environment accessible to all citizens is a major goal of the Ukrainian disability rights movement. Although some limited progress has been made in this area, for the most part, the built environment remains inaccessible to wheelchair users and others with disabilities. Issues of accessibility have been pursued most vigorously by rights activists in L'viv who have received support from the Canadian Centre on Disability Studies and other international institutions to implement accessibility promotion projects. Yaroslav Hrybalskyy, Director of the Independent Living Resource Center, has been an especially active proponent of accessibility issues. Hrybalskyy, who is based in L'viv but travels frequently to Kyiv, is the coordinator for accessibility concerns for NADU. In this capacity, Hrybalskyy has played a key role in drafting legislation (he was an author of Presidential Decree No.900) and coordinating seminars and conferences on accessibility issues. In 2006, Hrybalskyy was elected as a representative (deputat) in the L'viv regional government, and in this position has been able to advance accessibility issues even further in the L'viv region. Under Hrybal-

24. Personal Communication from Oleg Poloziuk to author, (Sept. 28, 2006) (on file with author). 
skyy's watch, handicapped accessible trolley buses have been integrated into the L'viv city public transport system, and accessibility related building codes are being enforced.

In these areas, Hrybalskyy has worked together with his colleague Mykola Swarnyk. Swarnyk has been a leader in the Ukrainian Parents' Movement for Disability Rights and was elected to the L'viv city government in 2006. One of Swarnyk's priorities is to ensure enforcement of accessibility laws. He has said that, because he is a well-known member of the disability rights movement, builders, businesspeople, and city officials know that he will not simply "look the other way" from building violations as others have done, and he will not accept bribes to approve construction that violates accessibility regulations. Swarnyk developed a system he hopes will encourage builders to conform to accessibility codes: violators of the codes will be required to pay fines into an "accessibility fund." The fund will then be used to make public buildings, like government offices and schools, handicapped accessible. As respected community activists with one foot in disability NGOs and one foot in government, Hrybalskyy and Swarnyk are well placed to foster reform and cultivate a culture enforcing the existing legislation on disability issues.

Together, these three case studies provide examples of strategies NGO activists might pursue to successfully promote a disability rights agenda in their communities in Ukraine today. To enhance employment opportunities for the disabled members of her organization, Iryna forged a partnership between representatives of NGOs, the state, and business, and simultaneously pursued a strategy of personification of disability issues. Similar to Iryna, in their quest to provide Ukrainian wheelchair users with locally produced active wheelchairs, Zoia and Sasha also coordinated the interests of disabled citizens, local businesspeople, and representatives of the state. Additionally, they contributed their own knowledge and expertise, and drew on the experience of their Swedish colleagues, to make their case and to pursue local innovations. The example of accessibility campaigns in L'viv also attests to the important contributions that support from abroad (in this case, Canadian disability rights experts) has made to implement a rights agenda in Ukraine. It likewise supports the argument that one of the best ways to move the disability rights agenda forward, and to solidify enforcement of protective legislation, is to field members of the movement for political office. Additionally, there are other strategies NGO activists in post-Soviet Ukraine can do to advance a disability rights agenda. 


\section{Looking Ahead: NGOs and the Future}

Based on my research with disability advocacy NGOs, I see the following strategies as key to strengthening the rights movement.

\section{A. Launch Information and "Image" Campaigns}

The disability-related legislation that was passed in the early 1990s in newly independent Ukraine, as well as subsequent legislation, was authored by elite actors and adopted in a top-down manner. This contrasts with disability rights history in the United States, where new ways of conceptualizing disability emerged out of disability advocacy communities and were leveraged to enact comprehensive legislation over a period of many years. These processes resulted in a fundamental shift in both the self-perception of people with disabilities and societal attitudes. Unfortunately, in Ukraine, the general population has not been exposed to debates over disability rights in any meaningful way. The Soviet-era history of social exclusion of the disabled, many of whom were institutionalized or isolated in their homes, has produced profound ignorance about disability, the disabled, and their potential to live full lives and contribute to society. Among the general public, disability rights is seen as a back-burner issue. A lack of basic statistical data about disabled populations compounds the problem.

In this context, NGOs need to direct more effort toward informing the public about disability issues and improving popular perceptions of disability and the disabled. As a part of this effort, civil society actors could initiate research on disability. Even basic statistics on persons with disabilities; types of disability; and residence, education, and employment characteristics of disabled persons would contribute on many levels to advancing a rights agenda and formulating services. Several television programs, such as the now defunct series "Podolannia" ("Overcoming"), on disability issues seem to have made positive impacts. NGOs could raise consciousness through similar programs and develop public service announcements. Also, it is curious that Ukraine's paralympic athletes, who have done exceedingly well in the last several Paralympic Games, have been almost completely detached from disability rights activism. Their success and positive public image could be harnessed to advance the disability rights agenda.

Avenues need to be found to shift public thinking about disability away from negative stereotypes, fear, and pity. Some activists in Ukraine have taken up the social model of disability, which locates disability not within the "impaired" body, 
but rather defines disability as social oppression, pointing to disabling environments and barriers that perpetuate and reinforce social exclusion and dependency. More can be done to educate the public about the social and environmental bases of disability. Akin to the social model is a universalizing model of disability, which argues that everyone, at some point in their lives, is likely to face disability. This makes disability an issue for everyone and broadens the terms of the debate. Both ways of conceptualizing disability could help generate public discussion and change societal atritudes.

Like the activists who organized the first Divis na mene event in Lutsk, rights activists need to pursue opportunities to facilitate interaction between citizens with and without disabilities and to promote a discourse of inclusion and interdependence. Placing more emphasis on inclusive education for children with disabilities (the Ukrainian educational system is, for the most part, non-inclusive, though some changes are occurring in higher education) ${ }^{25}$ would have a longterm, positive impact on children's attitudes toward disability and the disabled.

\section{B. Move Activists into Political Office}

Getting more members of the disability rights movement into local and national government is an important way to pursue the overall rights agenda, foster effective enforcement mechanisms, and give equal voice to diverse contingents of the movement. Such a move could help prevent the elite capture of disability issues that characterizes some aspects of the movement today.

Although some important advancements have been made by NGOs in educational and health care reform, it is difficult for civil society organizations to move disability rights forward in the absence of a willing state. At present, cadres in the various ministries that govern disability affairs (the Ministry of Labor and Social Policy, the Ministry of Health, and others) tend to be ill-informed about disability issues at home and abroad. Members of the rights movement, and especially people with disabilities themselves, have much to contribute to social service and state institutional reform. For all these reasons, disability advocacy NGOs should prioritize fielding their own candidates for political office.

25. See Raver, supra note 11, at 33-34. 


\section{Pursue International Partnerships}

Despite the well-known limitations of international development assistance and programs, there are cases where international partnerships in areas like disability rights can be very beneficial. In Ukraine, some transnational advocacy efforts in the areas of active rehabilitation, accessibility, and education have allowed Ukrainian rights activists to successfully pursue change in their communities. Activists have benefitted from opportunities to travel to the United States, Canada, and other countries to participate in seminars, meet fellow activists, and become familiar with different approaches to rights issues. Likewise, activists and scholars from abroad have traveled to Ukraine, not only to share their own strategies, but also to learn about local realities and movements for change.

\section{Conclusion}

Today, Ukraine finds itself poised at the edge of the European Union, and many in the country are debating Ukraine's own status as part of the "New Europe." This seems a crucial moment for rights activists to play the international card against the national and the local. Leveraging a discourse of European, Western, or international standards is one way to argue for the necessity of sweeping reform in the disability rights arena. Many Ukrainian activists I know are fond of the truism that a society's treatment of citizens with disabilities provides a good indicator of its commitment to democracy and human rights. Drawing on international examples to convince their compatriots that they have much further to go is one way activists might shift the terms of public discourse and lend more legitimacy to the disability rights agenda in post-socialist Ukraine. 


\section{Indiana University Press/Journals}

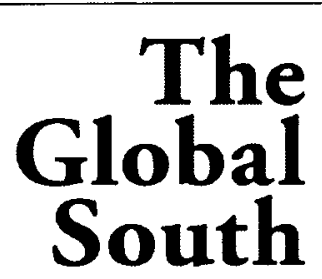

an interdisciplinary

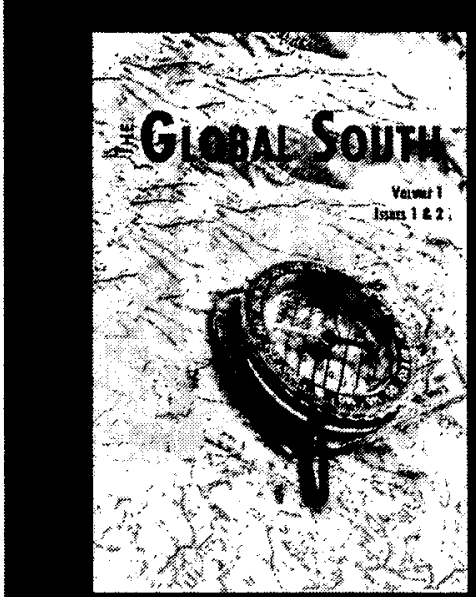
journal that focuses on how world literatures and cultures respond to globalization

PUBLISHED SEMIANNUALLY eISSN $1932-8656$ PISSN 1932-8648

800-842-6796/812-855-8817 http://inscribe.iupress.org Available in electronic, combined electronic \& print, and print formats

EDITED BY ADETAYO ALABI

The Global South is an

interdisciplinary journal that focuses on how world literatures and cultures respond to globalization, particularly how authors, writers, and critics respond to issues of the environment, poverty, immigration, gender, race, hybridity, cultural formation and transformation, colonialism and postcolonialism, modernity and postmodernity, transatlantic encounters, homes, and diasporas, and resistance and counter discourse, among other issues, under the superordinate umbrella of globalization.

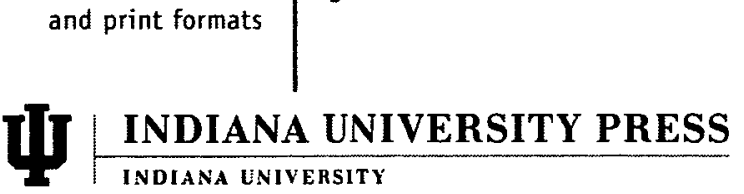

601 North Morton Street, Bloomington, Indiana 47404-3797 USA 